\title{
PHILOSOPHY
}

\section{THE PHENOMENON OF «MASS CONSCIOUSNESS» IN E. FROMM'S PHILOSOPHY}

\author{
Master of Religious Studies, Habriielian A. \\ Ukraine, Kyiv, Dragomanov National Pedagogical University \\ Applicant of the Department of Theology and Religious Studies
}

DOI: https://doi.org/10.31435/rsglobal_ws/31072019/6596

\begin{abstract}
ARTICLE INFO
Received: 20 May 2019

Accepted: 19 July 2019

Published: 31 July 2019

\section{KEYWORDS}

Mass Consciousness, Humanistic Radicalism, Erich Fromm, destructiveness, aggressiveness, conformism, psychoanalysis, social unconscious, society, existence,

ABSTRACT

In this article, the author considered the concept of «Mass Consciousness» in the philosophy of Erich Fromm. The phenomenon of «Mass Consciousness» was studied from the standpoint of E. Fromm's «Humanistic Radicalism», and was analyzed in comparison with classical Freudian psychoanalysis and other prominent thinkers of the twentieth century. It was found that according to Erich Fromm's social psychoanalysis, aggression is the result of social exclusion, mass consciousness, and conformism. The prevention of these phenomena can only be realized by a healthy humanistic society, in which faith, hope, love, understanding, sanity, mutual respect, empathy that cannot be explained by human instincts.
\end{abstract} personality, humanistic ethics.

Citation: Habriielian A. (2019) The Phenomenon of «Mass Consciousness» in E. Fromm's Philosophy. World Science. 7(47), Vol.2. doi: 10.31435/rsglobal_ws/31072019/6596

Copyright: (C) 2019 Habriielian A. This is an open-access article distributed under the terms of the Creative Commons Attribution License (CC BY). The use, distribution or reproduction in other forums is permitted, provided the original author(s) or licensor are credited and that the original publication in this journal is cited, in accordance with accepted academic practice. No use, distribution or reproduction is permitted which does not comply with these terms.

Introduction. In many anthropological theories, problems of mass consciousness have long been raised, but these problems are becoming more and more relevant. The concepts of «mass» and «Mass Consciousness» are considered from different points of view. Thus, D. Bell drew attention to the fact that they are treated with a multitude of people belonging to, for example, a class, and as an automated media audience that has neither tradition nor thought as a «synonym of ignorance». For other philosophers, the mass is a mechanized set and dehumanized element of society. Max Weber saw in this phenomenon people from the administrative strata, completely subordinates, who lost their self-esteem and are in a state of fear and insecurity [9, p. 124-136]. Gustave Le Bon defined the mass as a crowd in which people manifest themselves in the form of mass psychosis and operate based on instincts. In these and other similar characteristics of the mass and mass consciousness, there is a negative shade.

Research results. Many thinkers of the twentieth century, who created the concept of a mass man, saw in it the source of the threat to the existence of modern society and the person himself. Erich Fromm, who also revealed the phenomenon of destructiveness (destructiveness) in the mass consciousness as a paradoxical philosophical anthropological problem, came up to the deepest and most comprehensive study of these problems. In his work, he deeply and comprehensively considered issues related to the existence of man. Fromm reveals in a mass person not only negative moments but also the ability to change.

Like the aforementioned thinkers, as well as J. Ellul, G. Orwell, A. Huxley, L. Mumford, Erich Fromm believes that in a fully mechanized modern society, which seeks to maximize production and consumption or to manage with the help of computers, now the terrible ghost that represents the death of mankind is embodied. According to Fromm, in this Technotronic society, «there is a danger of the death of the human soul, the loss of control over one's personality» [6, p. 75], in which the cause of the destructive syndrome and conformism that are characteristic of the mass consciousness. By linking man's changes with 
the change of society and using enormous empirical and theoretical material in his numerous works, Fromm acts not only as an outstanding philosopher and psychologist but also as a sociologist, ethologist, culturologist, anthropologist and futurologist. He can be considered the creator of/ a completely new approach to anthropological problems, which led to important topical conclusions.

Pushing away from psychoanalysis, whose platform he considered insufficient to penetrate the problem, Fromm looked at a person not only as a carrier of the psychic existence but also as a social being (biopsychosocial), which was formed in specific historical conditions, where biological and mental refraction through social.

Many years of Erich Fromm's thinking about a man were philosophical reflections on society - his past, present, and future. Realizing the modern society as irrational, ill and leading many evidence of the degradation of the personality of the «mass man», Fromm nevertheless considers the real possibility of humanizing society as a result of the gradual change of the person who is able to understand the influence of mental and social factors, and eventually change.

This conclusion Fromm justifies in the book «The Revolution of Hope», which, like his work «The Anatomy of Human Destruction», is written in recent years of his life. Both works represent new moments of the anthropological concept of the author and contain great material for characterizing modern man and society [4, p. 24-26]. They are final.

Without being able to analyze in detail these works here, it should be noted that the most important questions for philosophical anthropology are: what is a person, why it is, how it changes, or whether a purposeful change in its characteristics is provided by Fromm, but the original answers are found on them. It is important to emphasize that the focus of all material refers to a modern person. It is the latter two works of Fromm devoted to the study of the modern «mass man falling into an even greater crisis», which is alarming for the future of mankind. Considering the main qualities that characterize the modern mass consciousness - destructiveness, aggressiveness, conformism, Fromm seeks an explanation for these phenomena, studying enormous scientific material, psychological, philosophical and political theories. His work, «The Anatomy of Human Destruction», is a profound, multidimensional study of the existence of man, in which Fromm continues to deviate from the concept of Freud, which exaggerates the biological in humans [2, p. 81]. He affirms the idea of a person as a social being introduces the new notion of «social unconscious» and opposes instincts, which, based on Freud's concept, emphasizes the «animal nature» of a person and defines her feelings and deeds as based only on instincts and natural motives. Replacing this point of view, Fromm, in particular, describes in detail the results of new studies in neurophysiology [3, p. 116].

Considering new approaches to understanding the existence of man, Fromm also criticizes the ideas of behaviorism. He writes that although instincts sees in man the result of the development of ancestral animals, and behaviorism, on the contrary, argues that «man is the result of directed education» [5, p. 55], the views of these currents are coming closer, because both of them see a man in a puppet who is at one end congenital factors, and on the other - acquired by upbringing. They, according to Fromm, make a general mistake, since they do not take into account the personality of the person himself, his freedom, his responsibility, and do not feel the actions of the person himself. It is in this opinion that the main opening of Fromm contains. In both works, the concept of a person responsible for what it is, despite the tremendous influence on her living conditions, is finally adopted. This conclusion seems paradoxical.

Analyzing, in particular, the sphere of feelings, passions, needs, value orientations, the lifestyle of a modern man, Fromm describes an almost completely new person. He argues that the person could not change under the influence of «megamachines» (the term taken from the work of Mumford «The Myth of the Machine»). By this concept, E. Fromm stands for modern technogenic civilization, which has features of a totalitarian society. Naming this society is also technological and analyzing it, Fromm shows the devastating impact on man, its nature and its complete dependence on it. In particular, according to Fromm, the main principles of the «mega-machine» are, according to Fromm, the following: «the principle of compulsory that from the technical point of view it is possible», «the principle of maximum efficiency and maximum productivity», «the principle of vertical dependence», «the principle of general control», etc. [8, 74-75].

As a result of applying these principles to the first place in society are not human values, but technical, the person is taken into account only in the form of punched cards, individualization becomes minimal, and «people-units» are easily manageable; where even the managers and bureaucratic elite, in contrast to the past, become part of this «megamachine». In such a society, according to Fromm, «the private environment of people's lives disappears»), as the interference of various institutions deepens and expands. The control of each person becomes common, even psychological testing leads to the 
coordination of behavior in the interests of technological society. Fromm analyzes in detail the changes that take place in the sphere of human feelings, needs, interests, and sentiments. His conclusions are unexpected and not entirely consistent with the already established views of philosophical anthropology, psychology, sociology, religious studies, theology, and ethics. The most important thing to note is that, when considering human feelings, he emphasizes that they are the same in any generation and they are well studied, but explained incorrectly - «the significance of a person» [6, p.40]. Fromm believes that even the «feelings and passions of the first group» such as faith, hope, love, tenderness, empathy, compassion, vulnerability, and fear, empathy, and others, cannot be explained by instincts.

They are the result of profound long-term biopsychosocial changes that are reflected like man, they are deeply rooted in being, in human existence. To the feelings of the «second group», Erich Fromm counts the ones that directly link the personality and society. He considers the most important sense of interest, defining it as «the main guiding program» and one of the most comprehensive forms of establishing «relations with the world», as well as a sense of responsibility and a sense of identity.

It is important to keep in mind that all the feelings of a modern person, has changed under the influence of the rapid development of industrial society, reflect the state of divisions, confusion, alienation. In particular, Fromm believes that since people are increasingly turning into a thing, there is an «identity crisis», which, being an important active organizing center for the personality, reflects the discrepancy in the assessment of human actions by themselves and others and the existence of the human person [1, p. 111].

Describing changes in human feelings, Fromm says that their direction has changed, they are filled with new content, some feelings are gone or disappear and new ones appear. All this, in his opinion, depends on the dehumanization of society and the growth of alienation. A characteristic, especially sensitive, discomfort felt by a person who still has a sense of vulnerability and is aware of the "ego» associated with the main issues of existence - «to have or be?» But this discomfort no longer applies to those for whom the main thing is «to have» and those who already represent a «mummified state of personality» and thereby protect themselves to some degree from the outside world [4, p. 69].

Fromm writes that the syndrome of aggression cannot be understood, referring to individual feelings of a person - love and hatred, good and evil, they should be considered in terms of the fundamental contradictions of human existence. They «are rooted in biological dichotomy: there are no instincts and no self-consciousness» [6, p. 41]. The notion of «social character» (as «social unconscious») and the concept of «primary» and «secondary» feelings and «passions» reveal the understanding of Fromm's process of forming the individual character and behavior, the orientation of the settings and «value orientations» that emanate from society. Dependence on the norms and requirements of society causes stress in a person and changes her feelings. Fromm, for example, pessimistically estimates the future in which people can «turn into robots with light schizophrenic changes in the psyche» [5, p. 105].

In general, the notion of destructiveness Fromm understands in a new way. He includes the concept of conformism and the concept of defensive aggression («pseudoaggression»), as well as destructiveness based on sharp stress, ecstasy, irrational behavior based on individual and collective narcissism, etc. He describes this behavior as a new concept - «benign aggression». Another form of destructiveness is called «malignant aggression». It is based on the «feelings of the second group», on existential passions and needs associated with tragic contradictions and a sharp sense of alienation, fear, hopelessness. Considering this kind of destructive behavior, Fromm pays almost half the work. The most characteristic manifestations of this type of destructiveness are sadism, masochism, and necrophilia. Criticizing the narrow understanding of these terms in the concepts of Freudism, he writes that in the sexual sphere manifests itself already in the very nature of man, for example, an active desire for power over other people, causing them suffering, and so on. As an illustration of the features of the sadistic nature, Fromm examines the nature and behavior of Stalin and others, and speaking of necrophilia, describes the nature and activities of Hitler, believing that this is a «clinical case» [5, p.52-53].

Based on his conception of social character as the nucleus of the personality structure inherent in most people in this culture, he writes that although the social nature is formed by society, it can be consciously changed, but then whether the society itself will change? [6, p. 70]. As already was noted, in his philosophical conclusions about the existence of man, he substantiates the thesis of the contradictory dichotomous nature of man: the tendency to the natural state of man - biophilia, which is, love for life.

The meaningful development of the problem is contained in the «The Revolution of Hope», where Fromm writes that there is a subconscious desire for a «baby» who has become accustomed to being wholly in someone's care. Indeed, with the fact that this trend exists in the minds of a modern mass person, one cannot but agree. But Fromm's hope is based on the fact that although the "social system» can do anything with a person, the formation of a person has a relative character. He implies 
that the awareness of a person of his position, of «divisions» and even of «breaking», of understanding the contradictions between reason and feelings, of his dependence, can stop the destructive tendencies of the individual and bring it to the path of self-gain, that is, to confirm in the consciousness of biophilia. Then humanistic tendencies in society will develop. Thus, a long-lasting bilateral process of humanization can lead to a fundamental transformation of man. This is the main idea of Fromm, a cross-cutting theme of all his works. In «The Revolution of Hope» it is expressed categorically: «We face the threat of a serious crisis of a modern person, and we can no longer wait for events and lose time. So far, there is hope...» [7, p. 29-30].

This hope, Fromm, thoroughly justifies, devoting almost half of the book to the development of the problems of humanizing technological society. He argues that the opportunity will be realized if the consciousness «of the overwhelming majority of people for whom the minds, the common sense and, of course, the love» are the greatest values [4, p. 88].

\section{Conclusions.}

1. Fromm is sure that hope for change, for the salvation of man from its devastating tendencies, exists. In this sense, Fromm's ideas are close to the ideas of A. Schweitzer and his concept of «reverence for life», as well as other theories of humanistic ethics.

2. The study of the ideas of Fromm about the destructiveness of the mass consciousness and the humanization of modern technological society is also interesting because its ideas are inexhaustible. Thus, Fromm's «new conception of man», the idea of the need for the humanization of society and destructiveness problems characterizing the mass consciousness, remains relevant.

\section{REFERENCES}

1. Cutter P., Muller T., Psychoanalysis. Introduction to the Psychology of Unconscious Processes, Moscow: Kogito-Center, 2011 [Кугтер П., Мюллер Т., Психоанализ. Введение в психологию бессознательных процессов, Москва: Когито-Центр, 2011 (Kutter P., Myuller T., Psikhoanaliz. Vvedeniye v psikhologiyu bessoznatel'nykh protsessov, Moskva: Kogito-Tsentr, 2011)].

2. Freud S., Basic psychological theories in psychoanalysis/ trans. to rus. M. V. Wolf, A. A. Spector, Moscow: AST, 2006 (Фрейд 3., Основные психологические теории в психоанализе/ пер. М. В. Вульф, А. А. Спектор, Москва: АCT, 2006 (Freyd Z., Osnovnyye psikhologicheskiye teorii v psikhoanalize/ per. M. V. Vul'f, A. A. Spektor, Moskva: AST, 2006).

3. Freud S., Psychoanalytic Etudes/ Comp. D. I. Donskoy, V. F. Kruglyansky, Minsk: Poppuri, 2010 [Фрейд 3., Психоаналитические этюды/ сост. Д. И. Донской, В. Ф. Круглянский, Минск: Поппури, 2010 (Freyd Z., Psikhoanaliticheskiye etyudy/ sost. D. I. Donskoy, V. F. Kruglyanskiy, Minsk: Poppuri, 2010)].

4. Fromm E., The Anatomy of Human Destructiveness, Moscow, LLC Publishing House AST-LTD, 1998. [Фромм Э., Анатомия человеческой деструктивности, Москва, ООО Изд-во АСТ-ЛТД, 1998 (Fromm E., Anatomiya chelovecheskoy destruktivnosti, Moskva, OOO Izd-vo AST-LTD, 1998)].

5. Fromm E., The Greatness and Limitations of Freud's Theory, Moscow: AST, 2000 [Фромм Э., Величие и ограниченность теории Фрейда, Москва: АСТ, 2000 (Fromm E., Velichiye i ogranichennost' teorii Freyda, Moskva: AST, 2000)].

6. Fromm E., The Soul of Man, Moscow, "Republic", 1992 [Фромм Э., Душа человека, Москва, «Республика», 1992 (Fromm E., Dusha cheloveka, Moskva, «Respublika», 1992)].

7. Fromm E., The Revolution of Hope, St. Petersburg, Yuventa, 1999. [Фромм Э., Революция надежды, Санкт-Петербург, Ювента, 1999 (Fromm E., Revolyutsiya nadezhdy, Sankt-Peterburg, Yuventa, 1999)].

8. Golovko U. V., Ethics of Responsibility - Actual Manifestations, Herald of MGU, No. 2 (78), Moscow, 2011 [Головко Ю.В., Этика ответственности - актуальные проявления, Вестник МГУЛ, №2 (78), Москва, 2011 (Golovko U.V., Etika otvetstvennosti - aktual'nyye proyavleniya, Vestnik MGU, №2 (78), Moskva, 2011)].

9. Weber Max, A Theory of Economic and Social Organization, tr. A.M. Henderson and T. Parsons. New York: Free Press, 2010. 